\title{
The role of economic, policy, and ecological factors in estimating the value of carbon stocks in Everglades mangrove forests, South Florida, USA
}

\section{Abstract}

Old growth mangroves in existing protected areas store more carbon than restored forests or plantations. Carbon storage in such forests has economic value independent of additionality, offering opportunities for policy makers to ensure their maintenance, and inclusion in climate change mitigation strategies. Mangrove forests of the Everglades National Park (ENP), South Florida, though protected, face external stressors such as hydrological alterations due to flooding control structures and agriculture impacts and saltwater intrusion as result of increasing sea level rise. Moreover, decreased funding of Everglades' restoration activities following the recent economic crisis (beginning 2008) threatens the restoration of the Greater Everglades including mangrove dominated coastal regions. We evaluated several economic and ecological challenges confronting the economic valuation of total (vegetation plus soil) organic carbon (TOC) storage in the ENP mangroves. Estimated TOC storage for this forested wetland ranges from $70-537 \mathrm{Mg}$ $\mathrm{C} / \mathrm{ha}$ and is higher than values reported for tropical, boreal, and temperate forests. We calculate the average abatement cost of $\mathrm{C}$ specific for ENP mangroves to value the TOC from $\$ 2-\$ 3.4$ billion; estimated unit area values are $\$ 13,859 /$ ha $-\$ 23,728 /$ ha. The valuation of the stored/legacy carbon is based on the: 1) ecogeomorphic attributes, 2) regional socio-economic milieu, and 3) status of the ENP mangroves as a protected area. The assessment of C storage estimates and its economic value can change public perception about how this regulating ecosystem service of ENP mangrove wetlands (144,447 ha) supports human well-being and numerous economic activities. This perception, in turn, can contribute to future policy changes such that the ENP mangroves, the largest mangrove area in the continental USA, can be included as a potential alternative in climate change mitigation strategies. 
27 Keywords: carbon storage; carbon economic value; the Florida Everglades; mangroves;

28 ecosystem services.

29 


\section{Introduction}

Mangrove wetlands provide a wide array of ecosystem services that benefit society including coastal protection, wood for fuel, water quality improvement, and support of fisheries (Nagelkerken et al., 2008; Alongi, 2011; Barbier et al., 2011). Furthermore, mangrove forests have the potential to store carbon in above and belowground biomass and in the soil (Kauffman et al., 2011). Previous studies (Donato et al., 2012, Alongi et al., 2015) indicate that the mean carbon storage in mangrove forests located in the Indo-Pacific region (i.e., 1,023 Mg/ha) could exceed the mean carbon storage attributed to tropical upland, temperate, and boreal forests (200$400 \mathrm{Mg} / \mathrm{ha}$ ) (Pan et al., 2011).

$$
\text { Carbon storage (i.e., the stock of carbon stored in plant biomass and soil) and }
$$
sequestration (i.e., the rate of removal of atmospheric carbon per unit of time by plants and soils) (Chapin, 2006) are recognized ecosystem services that contribute to climate change mitigation

42 (Alongi, 2012; Caldeira, 2012; Siikamaki et al., 2012). Deforestation and land-use change account for $8-20 \%$ of the total global anthropogenic $\mathrm{CO}_{2}$ emissions (IPCC, 2007) including the

44 loss of a third of the global mangrove area over the last 50 years (Valiela et al., 2001). Despite occupying only $0.7 \%$ of tropical forest area, mangroves deforestation contributes $10 \%(0.02-$ 47 et al., 2012).

One of the mangrove forests least affected by direct deforestation in subtropical latitudes is the Everglades Mangrove Ecotone Region (EMER) in southern Florida, USA (Rivera-Monroy

50 et al., 2011a). Despite being located in a protected area, the EMER is exposed to several external 51 stressors (e.g., hurricanes, freshwater diversion). Hydrological changes in the past 100 years 
52 have altered drainage patterns and reduced fresh water flows into Everglades estuaries by more

53 than 50\% (Smith et al., 1989), affecting nutrient and salinity gradients regulating mangrove

54 structure and productivity (Castañeda-Moya et al., 2013). Although relative sea level has

55 increased by approximately $0.3 \mathrm{~m}$ over the last century in South Florida (Ross et al., 2009; Zhang

56 et al., 2012), it is seawater intrusion into the main regional aquifer along the Everglades coastline

57 that has altered the spatial distribution and diversity of plant communities, including mangrove

58 forests (Saha et al., 2012).

The Everglades is undergoing a large spatial-scale restoration as part of the

60 Comprehensive Everglades Restoration Plan (CERP) which is expected to increase the quantity,

61 quality, and timing of fresh water throughout the mangrove ecotone, thus potentially altering its

62 productivity and spatial distribution (Rivera-Monroy et al., 2011b; Sklar et al., 2001). CERP is

63 also expected to enhance other significant ecological and economic benefits arising from a range

64 of ecosystem services such as groundwater purification, real estate, park visitation, open space

65 and fishing (McCormick et al., 2010). Yet, the recent economic downturn (beginning in 2008)

66 along with policy changes has led to a significant decrease in funding to continue restoration

67 activities (> 10 billion US dollars) as initially planned (Sklar et al., 2005), threatening the

68 restoration of the Everglades including the EMER. Assessing the quantity and economic value of

69 the legacy $\mathrm{C}$ stored in the EMER, which has not yet been investigated, can (a) send a strong

70 signal to concerned policy makers of the importance of long-term allocation of CERP funds for

71 ENP preservation, (b) establish a baseline for future comparisons to evaluate restoration goals,

72 and (c) present opportunities for U.S.A. to include the value of the C stored in ENP mangroves

73 in long-term climate change mitigation strategies, thus fulfilling its commitment to the 2015

74 Paris Agreement under the United Nations Framework Convention for Climate Change. Carbon 
storage in protected areas has an economic value independent of additionality (Zarate-Barrera and Maldonado, 2015), offering opportunities for policy makers to ensure their maintenance, and inclusion in climate change mitigation strategies. Strengthening of these stocks within existing protected areas, especially in old growth forests such as the ENP mangroves, can be an important part of a country's strategy to combat climate change (Campbell et al., 2008; Alongi, 2011).

(

Valuation of ecosystem carbon storage faces several challenges. First, there exists a large uncertainty regarding accurate estimations of $\mathrm{C}$ storage, particularly in coastal wetlands because of the dynamic nature of $\mathrm{C}$ cycling in coastal environments where hydrological conditions regulate the exchange of organic and inorganic carbon between land and adjacent coastal waters (Bouillon et al., 2008, Hopkinson et al., 2012; Rivera-Monroy et al., 2013). Further, these areas are increasingly threatened by human impacts since 10 per cent of the world's population and 13 per cent of the world's urban population live in the coastal zone (McGranahan et al., 2007; Hopkinson et al., 2012). The variability and uncertainty in mangrove primary production and C accumulation through space and time greatly influence the economic valuation of carbon storage (Alongi, 2011). Indeed, C storage in wetland ecosystems, including mangrove forests, could vary between short (month, years) and long (decadal, centennial) temporal scales. This temporal variability is reflected in the role of mangroves as $\mathrm{C}$ sinks or sources as a result of dynamic changes in net carbon fluxes that are influenced by the geomorphic setting interacting with latitudinal temperature and precipitation gradients (Barr et al., 2010; Barr et al., 2012; Barr et al., 2013; Fuentes and Barr, 2015; Ho et al., 2014; Maher et al., 2013; Troxler et al., 2015; Rovai et al., 2015). Although the number of studies assessing net $\mathrm{C}$ fluxes in mangrove wetlands is limited (e.g., Maher et al., 2013), some studies indicate that mangrove forests could become a net $\mathrm{C}$ sink on decadal and centennial timescales if not significantly affected by deforestation or 
major changes in land use (Alongi, 2001, Kauffman et al., 2014; Ezcurra et al., 2016). In the case of the ENP, its protected nature (i.e., National Park) has the potential to lock the stored organic C longer into the biological pool, in contrast to carbon in an ecosystem that is under direct and compounding human threats.

Second, the economic valuation of $\mathrm{C}$ varies with valuation methodologies (Hessen et al., 2004; Stockmann et al., 2013), not all of which are suitable for valuing the carbon in a particular ecosystem. Carbon prices are also influenced by several technological, regulatory, economic and social factors, and vary across countries and markets. As $\mathrm{C}$ sequestration rate for EMER is not currently available and is uncertain (Troxler et al., 2013, Rivera-Monroy et al., 2013), our goal is to value the legacy carbon stored in the ENP mangrove biomass and soil. We therefore investigated different $\mathrm{C}$ valuation methodologies to appropriately value the $\mathrm{C}$ storage in the Everglades mangroves. Moreover, global estimates of mangrove C storage or estimates derived from tropical mangroves cannot be directly transferred to the Everglades region because of its distinct geographical location, ecogeomorphic characteristics, and the nature of the presses (i.e., sea level rise) and pulses (e.g., hurricanes) influencing the functional properties of mangroves in the Everglades (Collins et al., 2011, Castañeda-Moya et al., 2010). While recognizing the above challenges, the purpose of our study is to conduct a first economic valuation of total (vegetation plus soil) organic carbon (TOC) storage in the mangrove forests of the Everglades National Park (ENP). To achieve this goal, we first estimated the physical quantity of stored TOC, and then performed an economic valuation of this ecosystem service. Although a number of mangrove carbon stock assessments are now available for neotropical regions (e.g., Kauffman et al., 2014; Hamilton and Lovette, 2015), there is a lack of information establishing the physical and economic baseline of $\mathrm{C}$ values to strengthen emerging 
121 carbon mitigation initiatives, particularly given the wide difference in the degree of carbon

122 storage magnitude (above and belowground) provided by different mangrove ecotypes (Ewel et

123 al., 1998, Twilley and Rivera-Monroy, 2009, Rovai et al., 2015). We expect the economic value

124 of the stored organic carbon in mangroves per unit area to be significantly higher than other

125 types of forests. Presently, despite the fact that the Everglades has the largest area of mangroves

126 in the continental USA $\left(1,445 \mathrm{~km}^{2}\right)$ (Simard et al., 2006), there are no regional estimates of the

127 TOC (aboveground, belowground, and soil carbon) stored and its associated economic value

128 (Rivera-Monroy et al., 2013, Troxler et al., 2013). We expect that the estimate of TOC in the

129 Everglades mangroves and its economic valuation will encourage similar quantifications in other 130 mangrove wetlands.

As a protected area, some of the major threats to the ENP and its ecosystem services

132 come from external stressors located outside the park boundaries (e.g., change in the

133 hydrological regimes upstream; Sklar, 2005). Managing such external factors is often a complex

134 process and requires a large scale regional assessment study. For instance, as Friess et al. (2015)

135 note, designing a Payment for Environmental Services (PES) mechanism to handle external

136 factors needs to carefully consider a series of complex steps - from the evaluation of onsite

137 large-scale impacts of stressors to willingness on the part of external stakeholders to take

138 mitigation action and/or to pay for such actions. Evaluating all those steps is beyond the scope of

139 this paper. Instead, our methodology focuses on the first logical step of estimating and valuing

140 the stored onsite carbon. Such valuation will provide a baseline of stored C (in physical and

141 monetary terms), serving as a benchmark for evaluating the impacts of restoration programs that

142 might occur over a long period of time. Because of the protected nature of our study site and year

143 to year variability and uncertainty in C sequestration (Alongi, 2011), it may neither be necessary 
144 or feasible to implement a PES system for legacy carbon. PES systems have often proved more

145 appropriate for services that are measurable in short intervals (e.g., C sequestration instead of C 146 storage) and with less uncertainty (Alongi, 2011).

\section{2. Methodology}

148

\subsection{Study Area: Everglades Mangrove Wetlands}

Mangrove forests in South Florida are located within the protected areas of Everglades National Park (ENP), Florida (Figure 1). The EMER lies on a carbonate platform between the freshwater marshes of the Everglades and the marine waters of the Gulf of Mexico and Florida Bay (Chen and Twilley, 1999a). Two major drainage basins, the Shark River Slough (SRS) and Taylor Slough (TS) discharge water through the western and eastern regions of the Everglades, respectively (Saha et al., 2012; Blanco et al., 2013). In contrast to other nutrient rich estuaries, the EMER mangroves are influenced by a highly oligotrophic and phosphorus-limited coastal area (Noe et al., 2001).

Multigradient patterns of resources, regulators, and hydroperiod control mangrove community structure and ecosystem function in the region (Castañeda-Moya et al., 2013). The tall $(\sim 18 \mathrm{~m})$ riverine mangroves along SRS store the highest aboveground biomass values, particularly close to the mouth of the estuary. The high aboveground productivity of the SRS mangroves is attributed to the dominant tidal hydrology and higher phosphorus availability in the soil (Chen and Twilley, 1999b; Castañeda-Moya et al., 2010). The mangrove forests throughout TS have lower aboveground productivity and are dominated by scrub mangroves $(<1.5 \mathrm{~m})$ with biomass < 50 Mg/ha (Coronado-Molina et al., 2004; Simard et al., 2006; Castañeda-Moya et al., 2013). These scrub forests are permanently flooded throughout the year with negligible tidal 
166 frequency (Castañeda-Moya et al., 2011; Rivera-Monroy et al., 2011a). A significant interaction

167 of hydrological and fertility gradients results in distinct mangrove ecotypes (i.e., riverine vs.

168 scrub) with differences in the allocation of aboveground and belowground biomass across spatial

169 scales throughout ENP-EMER (Castañeda-Moya et al., 2013).

170

171

172

173

174

175 included three main C pools: (1) aboveground biomass $\left(C_{A G R}\right),(2)$ belowground live roots $176\left(C_{B G R}\right)$, and (3) peat soils $\left(C_{B G S}\right)$.

177

178

179

180

181

182

183

184

185

186

187

\subsection{Total Organic Carbon in the EMER}

The total organic carbon (hereafter referred to as TOC and/or C) present in the

Everglades mangroves was estimated using data and methodologies from previous studies of tree height spatial distribution and associated biomass in both the Everglades and other tropical regions (Simard et al., 2006; Simard et al., 2008; Rivera-Monroy et al., 2013). The stored TOC

\subsubsection{Aboveground TOC $\left(C_{A G R}\right)$}

We used landscape level tree height data to determine total mangrove biomass in the EMER. A detailed description of the methods to estimate height can be found in Simard et al. (2006). Briefly, tree height was estimated using Shuttle Radar Topography Mission (SRTM) (February 2000) and Light Detection and Ranging (LiDAR) data. The SRTM data was calibrated using airborne LiDAR data and a high resolution USGS digital elevation model (Desmond 2003). Space Shuttle Endeavour was equipped with two radar antennas separated by a $60 \mathrm{~m}$ boom (baseline) operating at C-band and X-band. Airborne LiDAR data were collected using an Optech ALTM 1233 system operated by Florida International University on 15-16 April and 1416 May 2004. With a flight altitude of $500 \mathrm{~m}$ above the ground, flight speed of $210 \mathrm{~km} / \mathrm{hr}$, field of view angle of $40^{\circ}$, and pulse rate of $33 \mathrm{kHz}$, a 360 meter-wide swath of $13 \mathrm{~cm}$ wide laser 
188 footprints spaced approximately every $1.5 \mathrm{~m}$ beneath the flight path was produced; for the

189 location of LiDAR survey transects see Simard et al. (2006). For SRTM calibration purposes, the 190 elevation data was filtered with a 31x 31 mean filter (i.e., $30 \mathrm{~m}$ x $30 \mathrm{~m}$ area) and co-registered 191 the LiDAR data with the SRTM map with nearest neighbor interpolation. The Root Mean Square 192 Error (RMSE) of the LiDAR versus SRTM-L regressions was $1.8 \mathrm{~m}$ and a filter window of 0.9 193 ha (5 $\mathbf{x} 5$ pixels) was used to preserve sharp tree height edges that are characteristic of the 194 mangrove forests (Simard et al., 2006). Forest stand-level structural properties including tree height, basal area, and diameter at 196 breast height (DBH) were collected in several sites using the variable plot method across 22 197 sampling points. A total of 289 trees were sampled over approximately $2.4 \mathrm{~km}$. Moreover, plot 198 data in scrub mangrove forests in Biscayne Bay and Taylor Slough were incorporated in the 199 dataset to include biomass estimates across the entire range of mangrove canopy heights in the 200 EMER. Initial landscape level estimates of tree height were converted to biomass values using 201 published species-specific allometric equations for neotropical mangroves (Fromard et al., 1998; 202 Ross et al., 2000) and later updated using regional species-specific allometric equations obtained 203 in 2005-2006 (Smith and Whelan, 2006). For specific values of statistical variance and error 204 propagation in above- and belowground biomass estimates see original sources (Simard et al., 205 2006; Castañeda-Moya et al., 2011, 2013). Aboveground biomass was then converted to carbon 206 values based on plant carbon content of $\sim 44 \%$ (Ewe et al., 2006). This conversion factor is an 207 average value $(44 \% \pm 2 \mathrm{SE})$ of all species-specific tree components (e.g., tree trunk, leaves, 208 roots, etc.) across all mangrove sites in our study region (Castañeda-Moya et al., 2013), and is 209 similar to estimates in a wide range of mangrove forest types and latitudes (Alongi, 2012). 
Castañeda-Moya et al. (2011) estimated total (0-0.9 $\mathrm{m}$ depth) root biomass $\left(\mathrm{g} \mathrm{m}^{-2} ;<20\right.$ $\mathrm{mm}$ in diameter) for the six FCE-LTER sites (SRS-4, 5, and 6 and TS/Ph-6, 7 and 8) (Table 1).

214 Overall, a total of 229 soil cores were collected across all six mangrove sites to estimate root 215 biomass. Root cores $(0-90 \mathrm{~cm})$ were collected at each site using a PVC coring device $(10 \mathrm{~cm}$ 216 diameter x $45 \mathrm{~cm}$ length). Cores were sectioned into 0-45 and 45-90 cm depths and processed 217 individually in the laboratory. Root cores were rinsed with water through a 1-mm synthetic mesh 218 to remove soil particles, and live roots were separated by hand picking and sorted into size 219 classes ( $<2 \mathrm{~mm}, 2-5 \mathrm{~mm}, 5-20 \mathrm{~mm})$. Each root sample was oven-dried at $60^{\circ} \mathrm{C}$ to a constant 220 mass, and weighted. As part of the Florida Coastal Everglades Long Term Ecological Program

221 (FCE-LTER, http://fce.lternet.edu/) mangrove studies have been implemented since 2001 on 222 these six study sites encompassing the Taylor (TS/Ph-6, 7, 8) and Shark River sloughs (SRS-4, 5, 223 6) (Figure 1). Similar to the aboveground biomass carbon estimates, belowground biomass was 224 converted to carbon using the plant carbon content of 44\% (Table 1).

\subsubsection{Soil Carbon $\left(C_{B G S}\right)$ and Estimation of Total Organic Carbon}

The soil total (inorganic + organic fractions) carbon (TC) values to a depth of $0.45 \mathrm{~m}$ for

227 the six FCE mangroves sites were reported by Castañeda-Moya et al. (2013). In that study, four 228 soil cores were collected at each site using a PVC suction-coring device $(15 \mathrm{~cm}$ diameter $\mathrm{x} 45$ 229 cm length; Meriwether et al., 1996). Cores were extruded and sectioned into 0-2 cm intervals 230 using a custom-made incremental soil core extruding apparatus. Soil sections were oven-dried at $23160^{\circ} \mathrm{C}$ to a constant mass and weighted to estimate soil bulk density. Samples were ground with a 232 Wiley Mill (250 $\mu \mathrm{m}$ mesh screen) and duplicate subsamples were analyzed for TC 233 concentrations using an ECS 410 Elemental Analyzer (Costech Analytical Technologies, Inc., 
234 Valencia, CA). To determine the TOC fraction for all study sites, a concentrated (12M HCL)

235 acid fumigation procedure was applied to all soil samples to remove the inorganic (carbonate)

236 fraction (Harris et al., 2001). Soil TOC values were then extrapolated to values per unit area

237 (Table 1). Soil and peat formation is strongly linked to mangrove production in the Everglades

238 (Chen and Twilley, 1999a) where peat deposits vary in thickness from 0.5 to $6.5 \mathrm{~m}$ across the

239 landscape (Ewe et al., 2006). In the Shark River region, pollen analysis in a $5.25 \mathrm{~m}$ depth soil

240 core at the mouth of this estuary (4 km from SRS-6 site) indicates that the underlying peat started

241 accumulating about $5250 \mathrm{cal}$ yr BP (Yao et al., 2015). Mangrove vegetation in this region started

242 to appear from 3,800 cal yr BP and became dominant by $1150 \mathrm{cal}$ yr BP (at approximately $1.4 \mathrm{~m}$

243 depth). Prior to mangrove establishment, the vegetation community in the study area was

244 apparently dominated by upland taxa and marsh vegetation ( 5700 to 3800 cal yr BP). In

245 contrast, mangroves in the Taylor Slough region are younger forests and more recently

246 established by colonizing this region. For instance, mangroves in TS/Ph-6 have encroached

247 inland approximately $1.5 \mathrm{~km}$ from Florida Bay during the past 50 years due to reductions in

248 freshwater drainage into this region along with a gradual increase in sea level (Ross et al., 2000).

249 As a result, the mangrove peat overlying marl at this site is less than $0.3 \mathrm{~m}$ depth, in contrast to

250 peat depths of about 0.5 to $1 \mathrm{~m}$ at TS/Ph-7 \& 8 (Ewe et al., 2006). Thus, because of the large

251 spatial variation in peat depth and difference in age of soil formation between regions, and

252 current level of certainty in C origin (upland/freshwater/brackish vegetation vs. mangrove), we

253 estimated soil TOC content down to $0.9 \mathrm{~m}$ depth in the Shark River region and down to $0.45 \mathrm{~m}$

254 in the Taylor River region to provide a conservative estimate of landscape level mangrove

255 organic C storage in the EMER (Table 1). 
We estimated the TOC mean and median values for above $\left(\mathrm{C}_{\mathrm{AG}}\right)$ and belowground root

257 biomass $\left(\mathrm{C}_{\mathrm{BGR}}\right)$ and soil organic carbon $\left(\mathrm{C}_{\mathrm{BGS}}\right)$ using all data sets available for each study site

258 (Table 1). We summed both the above- and belowground $\mathrm{C}$ and soil $\mathrm{C}$ pool (limited to $0.9 \mathrm{~m}$ for 259 Shark River and to $0.45 \mathrm{~m}$ for Taylor River region) and derived a median carbon storage value 260 for the ENP-EMER mangroves (Table 1, 335.6 $\pm 88.1 \mathrm{MgC} \mathrm{ha}^{-1}$ ) to account for intrinsic 261 variability due to sample size and as performed in other studies (e.g., Alongi et al., 2015, 262 Murdiyarso et al., 2015). We also assessed the uncertainty of the median value by calculating its 263 standard error considering a non-normal, skewed distribution of $\mathrm{C}$ values for each site and 264 calculated the standard error of the mean value for each $\mathrm{C}$ source using all sites $(\mathrm{n}=6)$ (Taylor, 265 1997; Chave et al., 2004) (Table 1).

\section{Selection and Development of Carbon Prices}

Upon analysis of different valuation methodologies, we performed a comparison of C

269 prices that included estimates based on social costs of carbon (SCC), marginal abatement costs 270 (MACs), and market prices. All values were converted to the common unit of 2015 U.S. dollar 271 per ton of $\mathrm{C}$.

Social cost of carbon, also referred to as marginal damage cost, reflects what society is 273 theoretically willing to pay to avoid the damages caused by increased C emissions (Price et al., 274 2007). We derived an estimate for the SCC by using social cost of $\mathrm{CO}_{2}$ estimates published by

275 the U.S. Government Interagency Working Group for regulatory analysis of projects that reduce 276 emissions (Interagency Working Group on Social Cost of Carbon, United States Government, 277 2013). We used the SCC of $\mathrm{CO}_{2}$ for the year $2015\left(\$ 36 / \mathrm{tCO}_{2}\right.$ in $\left.2007 \$\right)$, inflated it to 2015 USD 
$278\left(\$ 46 / \mathrm{tCO}_{2}\right)$ by applying an annual inflation rate of $3 \%$, and thereafter calculated the social cost of 279 carbon $(\$ 167 / \mathrm{tC})$ (conversion factor: $\left.1 \mathrm{tC}=3.67 \mathrm{tCO}_{2}\right)$. emissions or loss from the storage (Ramirez et al., 2002). To derive an abatement cost of mangrove $\mathrm{C}$ relevant to the Everglades, we used the cost associated with restoration of the historic sheet flow of water across the Everglades by the Comprehensive Everglades Restoration 284 Plan (CERP) (Carter, 2002). The primary goal of CERP is to capture and store freshwater that is 285 currently discharged into the ocean and use $80 \%$ of that freshwater for the preservation of the natural habitat and species. The initial cost estimated by the South Florida Ecosystem

287 Restoration Task Force was \$7.8 billion with an annual cost of \$182 million (Carter, 2002). We converted the 1998 costs to 2015 USD (initial cost: $\$ 12.8$ billion, annual cost: $\$ 300$ million) by compounding at $3 \%$ annual rate. As only $80 \%$ of these costs were allocated for the preservation of the natural habitat (Carter, 2002), initial 2015 costs amounted to $\$ 10.3$ billion and annual costs were \$240 million. The present value of the annual costs over the project's lifetime was estimated as $\$ 8$ billion (at 3\% discount). The total cost of preserving the natural habitat in Everglades, calculated as the sum of the initial and annual costs, was $\$ 18.3$ billion. As the mangrove forests $(144,447$ ha) encompass $14.86 \%$ of the total Everglades area $(971,660$ ha) covered under CERP, the cost of preserving the Everglades mangroves was calculated as $\$ 2.72$

296 billion. Thus, we estimated the average abatement cost of the mangrove $\mathrm{C}$ in Everglades as $297 \$ 56 / \mathrm{tC}$ (Table 2). for our study area. To estimate the market value for C, we used RGGI's 2014 average auction 
301 clearing price $\left(\$ 4.72 / \mathrm{tCO}_{2}\right)$ (Potomac Enterprises, 2015), converted it to $2015 \$\left(\$ 4.86 / \mathrm{tCO}_{2}\right)$, and

302 then calculated the market price of $\mathrm{C}(\$ 18 / \mathrm{tC})$ (conversion factor: $\left.1 \mathrm{tC}=3.67 \mathrm{tCO}_{2}\right)$. For

303 comparison, we also estimated the $\mathrm{C}$ value by using the 2014 international voluntary market

304 price of $\$ 3.80 / \mathrm{tCO}_{2}$ (Forest Trends Ecosystem Marketplace, 2015), and converted it to 2015

305 price of $\$ 14.36 / \mathrm{tC}$. The 2014 year was dominated by the Reduction of Emission by Deforestation

306 and Degradation (REDD+) market, which sells carbon offsets based on avoided deforestation. currently not in a position or are not willing to pay a full price required to supply the benefits of

C storage or sequestration. Estimates for SCC and MACs are derived using quantitative economic models that combine scientific knowledge on climate change with socio-economic aspects of economic growth under possible climate change scenarios (Ding et al., 2010). The

312 presence of uncertainties of key parameters in the climate change models and the type of model

313 used to estimate $\mathrm{C}$ prices contribute significantly to the uncertainty of model outputs.

314 Nevertheless, the average abatement cost of mangrove $\mathrm{C}$ calculated in our study $(\$ 56 / \mathrm{tC})$ is 315 based on cost estimates of an existing functional project (CERP) and not on future projects. 316 Additionally, the above MAC-based price estimated using the CERP-related costs is more 317 conservative than the SCC-based price.

\section{4. Results and Discussion}

\subsection{Carbon Storage}

There were significant differences in aboveground biomass (Castañeda-Moya et al.,

$3212013)$ and carbon storage ( $<<0.005$, Table 1) between Shark and Taylor rivers because of the

322 differences in forest structure characterized by different mangrove ecotypes (riverine vs. scrub), 
323 with aboveground C values 12.4 times higher in Shark River sites relative to Taylor sites (Table 324 1). In contrast, belowground root $C$ values were relatively similar between these two basins 325 ranging from 10.6 to $20.6 \mathrm{Mg} \mathrm{C}^{-1}$ across all sites. However, when comparing total vegetation 326 (aboveground + belowground roots) C storage between basins, Shark River allocated 77.4\% of 327 the carbon to aboveground (i.e., trunk), while scrub mangroves in Taylor River stored more C 328 belowground (78.5\%) relative to aboveground (21.5\%). This differential allocation in carbon 329 between above-and belowground components across sites and basins is also reflected in the 330 root:shoot ratios, with lower ratios in the Shark River sites (range: 0.2 to 0.5 ) compared to the 331 Taylor River sites (range: 1.9 to 9.7). The mean total (vegetation + soil) ecosystem TOC was 2.8 332 times higher in Shark River (473 $\mathrm{Mg} \mathrm{C} \mathrm{ha}^{-1}$ ) relative to Taylor River (169 $\left.\mathrm{Mg} \mathrm{C} \mathrm{ha}^{-1}\right)$, with the 333 lowest TOC allocation at TS/Ph-6 (Table 1). The vegetation $\mathrm{C}$ pool accounted for $15 \%$ of the 334 total ecosystem $\mathrm{C}$ storage for both basins, whereas the soil $\mathrm{C}$ pool represented the largest fraction 335 of $\mathrm{C}$ storage in each site ranging from $77-90 \%$. These results show that riverine mangroves 336 along Shark River store more C relative to scrub mangrove forests, which are P-limited and 337 influenced by long flooded hydroperiods restricting growth and development (Castañeda-Moya 338 et al. 2013). Our results also support the findings from other studies (e.g., Donato et al., 2011; 339 Kauffman et al., 2014, Adame et al., 2013) indicating that regardless of the dominant mangrove 340 ecotype (riverine vs. scrub), the majority of carbon is stored in the soil. The higher C allocation 341 in the western region (Shark River) of Everglades National Park is associated with the presence 342 of deep soil peat layers compared to the eastern region where shallow peat deposits and scrub 343 mangrove forests dominate the Everglades landscape (Simard et al., 2006; Castaneda-Moya et 344 al., 2013; Yao et al., 2015). 


\subsection{Comparison of $\mathrm{C}$ storage with other forests}

Current estimates of carbon stock density in tropical, boreal, and temperate forests are 242, 239, and $155 \mathrm{Mg} \mathrm{C} /$ ha, respectively (Pan et al., 2011). In the case of mangrove forests, a number of studies have shown variable values depending on the geomorphic setting, but overall mean $\mathrm{C}$ stocks are significantly higher than those for terrestrial forests. For example, Donato et al. (2012) estimated an average total (aboveground + belowground + soil) carbon storage of $1,023 \mathrm{Mg} \mathrm{C} / \mathrm{ha}$ at variable soil depth in the Indo-Pacific region in forest stands classified as oceanic and estuarine mangroves. Similar values were obtained in mangrove forests from the tropical Pacific (Micronesia, Republic of Palau: 830-1218 Mg C ha-1) (Donato et al., 2012). Our median $\mathrm{C}$ storage estimates for the EMER indicate that mangrove forests in this region store 335.6 \pm 88.1 Mg C/ha (Table 1) (range: $0.45-0.9 \mathrm{~m}$ soil depth). We compared our values to those obtained in other locations in the Americas including the Caribbean region (Sian Kaan) (Adame et al., 2013), the Pacific coast of Mexico (Bahia Magdalena, Baja California; Ezcurra et al., 2016) and the Dominican Republic (Kauffman et al., 2014) . Carbon stocks in the Sian Ka'an Biosphere Reserve, a karstic-dominated environment similar to the ENP, were significantly different in tall (10-14 m: 127.0-145.6 MgC/ha), medium (5-11m: 80.8-82.7 MgC/ha), and scrub (0.1-2 m: 4.9-11.7 MgC/ha) mangrove forests. C stocks in mangrove wetlands in Bahía Magdalena, a non-topographically constrained lagoon on a flat coastal plain under a semi-arid climate were $<150 \mathrm{MgC} / \mathrm{ha}$, which were obtained at a range of 0.9-1.6 $\mathrm{m}$ soil depth. The highest values reported by Ezcurra et al. (2016) were obtained in tropical latitudes where riverine mangroves were widely variable and ranged from 100 to $800 \mathrm{MgC} / \mathrm{ha}$ (La Encrucijada, Mexico). Mangrove wetland carbon stock estimates ( 1 $\mathrm{m}$ depth) obtained in coastal regions in the Dominican Republic also varied depending on forest stand stature; the highest $\mathrm{C}$ stock (580 \pm 40 
$\mathrm{MgC} / \mathrm{ha})$ was measured in tall mangrove forests $(>10 \mathrm{~m})$ and the lowest $(320 \pm 210 \mathrm{MgC} / \mathrm{ha})$ in dense stands of scrub forests $<3 \mathrm{~m}$, which showed a high variability in C stock values (Kauffman et al., 2014). These neotropical sites, including our study area, are strongly impacted by tropical storms, which can influence total aboveground biomass, tree stature and productivity (Farfán et al., Smith et al., 2009).

About $4 \%$ percent of the EMER carbon storage value is partitioned in the aboveground biomass and $96 \%$ is belowground (roots + soil). This belowground value is comparable to estimates from other mangrove areas in the Indo West Pacific (IWP, old world) and Atlantic East Pacific (AEP) (Neotropics). For instance, in the IWP mangroves soil C ranges between 71-98\% of the total value in estuarine mangrove sites and 49-90\% in oceanic sites (Donato et al., 2012). In the AEP region, values are similar, ranging from 65 to 99\% (Adame et al., 2013, Kauffman et al., 2014). In comparison, tropical forests store $56 \% \mathrm{C}$ in biomass and $32 \%$ in soil, while boreal forests store $20 \%$ in biomass and $60 \%$ in soil (Pan et al., 2011). These results underscore the significant contribution of soil C storage in these forested wetlands worldwide compared to other terrestrial biomes.

\subsection{Economic Criteria for Valuation of Mangroves}

The estimated values for C storage in ENP mangroves are $\$ 4,819 / \mathrm{ha}, \$ 6,041 / \mathrm{ha}$, and $\$ 56,045 /$ ha based on the international voluntary market $(\$ 14.36 / \mathrm{tC}), \mathrm{RGGI}(\$ 18 / \mathrm{tC})$, and the social cost of carbon $(\$ 167 / \mathrm{tC})$ derived by the US. Interagency Working Group 2013 estimate, respectively. The average abatement cost based on CERP costs $(\$ 56 / \mathrm{tC})$, yields a value of $\$ 18,794 /$ ha for the C stored in ENP (Table 2). Given the variability in C prices (as seen in Section 3.2), we developed a simple set of general economic criteria for valuing ecosystem C, 
391 based on the type of carbon (stored or sequestered), the robustness of $\mathrm{C}$ markets, and the stage at 392 which a country's policy cycle is at a given time. These criteria can act as a guide for setting the appropriate C price to value mangrove forests in general and those in South Florida in particular.

The methodology for the economic valuation of stored carbon differs from that for

395 sequestered carbon (Ramirez et al., 2002). The social cost of carbon, which reflects the economic

396 value of the damage associated with incremental increase in C emissions (Price et al., 2007),

397 would be appropriate for valuing periodic C sequestration (Ramirez et al., 2002). However, our

398 goal in this study is to value the legacy carbon stored in the Everglades biomass and soil at the

399 centennial scale. Marginal abatement costs represent the cost of preserving the existing

400 mangrove forest and the associated stored carbon. Since the primary goal of CERP is to preserve

401 and maintain the natural habitat in the Everglades, including mangroves, by restoring the historic

402 flow of freshwater, we consider the average abatement cost derived from CERP costs $(\$ 56 / \mathrm{tC})$ as

403 the most appropriate for carbon valuation in this study.

404 Carbon markets and REDD+ schemes consider C sequestration, and not storage, for 405 pricing ecosystem carbon (Alongi, 2011; Zarate-Barrera and Maldonado, 2015). Moreover, the

406 low C market price in current U.S. markets (RGGI: \$18/tC) reflects the disparity between what 407 people are actually paying and what people might be willing to pay. The current price

$408(\$ 14.36 / \mathrm{tC})$ of carbon in the international markets like REDD+ is even lower. Carbon markets do 409 not include $\mathrm{C}$ storage in protected areas as yet (Zarate-Barrera and Maldonado, 2015), and until 410 they do so, the current market prices may be unsuitable for policy development. However, these 411 tentative/preliminary prices could at best provide a benchmark for stable and robust $\mathrm{C}$ prices.

412 Thus, our study uses the average abatement cost of carbon $(\$ 56 / \mathrm{tC})$ for the valuation of $\mathrm{C}$ stored 413 in ENP (Table 2). 


\subsection{Ecological Criteria for Valuation of Mangroves}

In this section, we offer general recommendations for ecological factors to be considered when setting the price for $\mathrm{C}$ storage (as in this study) and sequestration in mangroves.

(1) Forest age. A mature and intact mangrove forest, such as the EMER, has more interconnectivity and functional redundancy, and provides a variety of ecosystem services in 419 comparison to younger, single-species plantations (Alongi, 2012; Rivera-Monroy et al., 2013). 420 For mature, older forests like the EMER, where periodic sequestrations are uncertain and their 421 estimates are limited (e.g., Troxler et al., 2013, Rivera-Monroy et al., 2013), C valuation may 422 include $\mathrm{C}$ stored over a long period of time (decades, centuries). As the $\mathrm{C}$ sequestration rate 423 specific for ENP mangroves is not available in current literature, we only valued its $\mathrm{C}$ storage. It 424 is critical not to use market prices alone, the framework of payment for ecosystem services 425 (Alongi, 2011), or social costs of carbon (Ramirez et al., 2002) to value the C storage in such 426 mature forests. In our study, we therefore used the abatement cost of $\mathrm{C}$ based on CERP costs.

(2) Variability in ecosystem functions and services. Carbon valuation must take into

428 account not only the distinct geomorphic settings (e.g., delta vs. karstic) where mangroves 429 develop, but also the influence of landscape level disturbances when monitoring $\mathrm{C}$ storage in the 430 long-term. Both mangrove sequestration capabilities and limits are non-linear and vary 431 significantly with time and space, especially in coastal regions subject to major natural (e.g., 432 tropical storms) and human disturbances (Ewel et al., 1998; Twilley and Rivera-Monroy, 2009).

(3) The status of mangrove forests as a protected area. Although protected areas are

434 primarily designated for biodiversity conservation, they are also recognized as an alternative to 435 regulate climate through $\mathrm{C}$ storage (Campbell et al., 2008), independent of additionality. If the 
436 regulations are properly enforced, forests in protected areas could become significant sinks of

437 carbon. The valuation of $\mathrm{C}$ sequestration and storage services in protected areas depends on the 438 magnitude of $\mathrm{C}$ stored, the level of management and enforcement, the amount of resource

439 extraction/use permitted, and the governance and land-use change pressures that determine the 440 capability of the system to store carbon (Campbell et al., 2008). For example, mangroves in the 441 EMER are a unique case in comparison to other mangrove forests in the Americas since they 442 have not been influenced by direct (human settlements) or indirect extractive uses (e.g., wood, 443 silviculture), or significant eutrophication impacts during the last 150 years.

The carbon storage in ENP mangroves is high and compares to other mangrove forests in 445 developing countries in the Americas (Adame et al., 2013; Suárez-Abelenda et al., 2014; Duque446 Estrada et al., 2015). Mangrove-dominated coastal regions are under constant pressure derived 447 from human activities despite their designation as protected areas and as part of a network of 448 national parks system or under the assignations of RAMSAR sites or Biosphere Reserves 449 (Rivera-Monroy et al., 2004). To compound the problem, it is estimated that of the total global 450 mangrove area estimated using Landsat imagery $\left(137,760 \mathrm{~km}^{2}\right)$ in 2000 , only $6.9 \%$ is protected 451 under the Convention on Biodiversity (Giri et al., 2011). In the case of mangroves in the 452 Americas, protected areas that lie in more restrictive International Union for Conservation of 453 Nature (IUCN) management category (e.g., categories I-II) are more effective in reducing 454 deforestation (Clark et al., 2008). Yet, protected areas also face net loss when deforestation 455 pressures are avoided in the core zone because large spatial scale impacts are transferred into the 456 park boundaries as result of changes generally occurring in adjacent, unprotected areas that are 457 hydrological and functionally connected to the protected/park area (Rivera-Monroy et al., 2004). 


\subsection{Economic Valuation of the Carbon Stored in EMER}

Considering both the ecological nature of the study region and the economic criteria for

461

462

463

464

465

466

467

468

469

470

471

472

473

474

475

476

477

478

479

480

481 valuation, we use the average cost of abatement derived from CERP costs $(\$ 56 / \mathrm{tC})$ as the most appropriate to value the Everglades mangrove $\mathrm{C}$ since this cost indicates the cost of preserving the stored carbon within these forests. SCC-based valuation is more appropriate for C sequestration (Ramirez et al., 2002) and not so much for C storage in the Everglades where mangrove wetlands are protected, and deforestation and the attendant carbon loss are not an immediate threat to the ecosystem. Until robust carbon markets that consider $\mathrm{C}$ stored in protected areas evolve and the resultant carbon market prices represent a balance between what the society would be willing to pay and what it costs to supply $\mathrm{C}$, the current market prices may not be appropriate for valuation of stored carbon in EMER. Moreover, the main purpose of the valuation in this study is not to make an economic and ecological justification for receiving substantial market-based payments. As long as the CERP policy focuses on preventing the loss of legacy $\mathrm{C}$, the abatement cost would be a more appropriate valuation tool. Accordingly, the value of the $\mathrm{C}$ stored in EMER is $\$ 18,794 /$ ha or $\$ 2.7$ billion (Table 2). This value reflects the potential loss of $\mathrm{C}$ in monetary terms if society fails to prevent the degradation of mangroves because of external threats in the future.

One should exercise caution when comparing the above per-hectare $\mathrm{C}$ value with those reported in other studies because of the variation on the basis of pricing. Also, there is a wide range of assumptions and environmental processes (e.g., geomorphic, hydrological) underlying C estimation in studies reported in section 4.2. For the sake of illustration, we multiply our abatement cost price of $\$ 56 / \mathrm{tC}$ with the $\mathrm{C}$ estimates of other studies to derive the following results. Based on the Pan et al. (2011) C storage estimate, the value of C stock in tropical, boreal, 
482 and temperate forests would be $\$ 13,552 / \mathrm{ha}, \$ 13,384 / \mathrm{ha}$, and $\$ 8,680 /$ ha, respectively. Using

483 Donato et al. (2012) estimate of C storage of 1,023 Mg C/ha in the Indo-Pacific oceanic and

484 estuarine mangroves, the $\mathrm{C}$ value is $\$ 57,288 / \mathrm{ha}$. Similarly, the $\mathrm{C}$ stock in mangrove forest with a

485 medium tree height (5-11m tall, (e.g., Sian Ka’an Biosphere Reserve) would be worth \$4,525/ha

486 to $\$ 4,631 /$ ha; whereas in the mangrove wetlands in the Dominican Republic (Kauffman et al.,

487 2014), the $\mathrm{C}$ value would be $\$ 32,480 /$ ha and $\$ 17,920 /$ ha for tall mangrove forests and scrub

488 forests, respectively. Clearly, the above values would be lower if we base our valuation on the

489 international voluntary market price or regulatory market price.

\section{5. Conclusion}

The aim of our study was to evaluate $\mathrm{C}$ pricing methodology and develop an appropriate

492 economic value of aboveground and belowground $\mathrm{C}$ pools in mangrove wetlands of the Florida

493 Everglades. The estimation of clear, quantifiable carbon stored in the Everglades mangrove

494 ecosystem can have several implications. Our carbon storage estimates may be considered as a

495 benchmark for establishing the costs of inaction associated with the failure to prevent such losses

496 in C stock. In addition, mangrove restoration programs will be increasingly needed as a

497 consequence of human and natural impacts in mangroves outside the ENP. In such cases,

498 estimates for the value of C storage in ENP mangroves can be based on MACs or more

499 specifically, the average abatement cost estimated in this paper $(\$ 56 / \mathrm{tC})$ to perform the cost-

500 benefit analysis of mangrove restoration.

Finally, we highlight limitations of the study. The $\mathrm{C}$ values estimated in this paper have a

502 wide range for two main reasons. First, the estimation of the $\mathrm{C}$ storage itself is influenced by

503 significant variances in the $\mathrm{C}$ stocks of different forest components. There is a large spatial 
gradient in mangrove biomass distribution that reflects the hydrological and nutrient fertility heterogeneity, and thus of the C stocks across the landscape (Childers et al., 2006, RiveraMonroy et al., 2011a, Castañeda-Moya et al., 2013). Still, we consider our already conservative values a first-rate approximation and a robust baseline that could be improved upon as more long-term sampling points are added across the region in the future to improve the $\mathrm{C}$ value spatial resolution. Second, there is no single ideal economic value for carbon, which varies widely depending on the political and economic environment of the natural resource in question. Therefore, the values estimated in this study must be used with caution and in reference to appropriate contexts. Further, carbon storage is only one of the several ecosystem services that the EMER mangroves provide. Our estimated economic value of carbon storage is just a component of the total economic value of the mangrove ecosystem. Future studies on the valuation of other ecosystem services in the region can help in determining a spatially explicit comprehensive value.

Acknowledgement: This study was funded by the National Science Foundation under the Water and Climate Sustainability program (Award \# EAR-1039223) and the Florida Coastal Everglades Long-Term Ecological Research program (Grant No. DEB-9910514, Grant No. DBI-0620409, and Grant No. DEB-1237517). Partial funding was also provided by the NASA-JPL project (LSU Subcontract\# 1452878) "Vulnerability Assessment of Mangrove Forest Regions of the Americas". We would like to thank Dr. Keqi Zhang, Daniel Gann, and Himadri Biswas for their valuable support in using GIS methodology. 
527

528

529

530

531

532

533

534

535

536

537

538

539

540

541

542

543

544

545

546

547

548

549

550

551

552

553

554

555

556

557

558

559

Adame, M.F., Kauffman, J.B., Medina, I., Gamboa, J.N., Torres, O., 2013. Carbon stocks of tropical coastal wetlands within the karstic landscape of the Mexican Caribbean. PLoS ONE 8 , e56569.

Alongi, D., 2011. Carbon payments for mangrove conservation: Ecosystem constraints and uncertainties of sequestration potential. Environmental Science \& Policy, 14(4), 462-470. doi:10.1016/j.envsci.2011.02.004.

Alongi, D., 2012. Carbon sequestration in mangrove forests. Carbon Management, 3, 313-322.

Alongi, D.M., Murdiyarso, D., Fourqurean, J.W., Kauffman, J.B., Hutahaean, A., Crooks, S., Lovelock, C.E., Howard, J., Herr, D., Fortes, M., Pidgeon, E., Wagey, T., 2015. Indonesia's blue carbon: a globally significant and vulnerable sink for seagrass and mangrove carbon. Wetlands Ecology and Management, 24, 3-13.

Barbier, E.B., Hacker, S.D., Kennedy, C., Koch, E.W., Stier, A.C., Silliman, B.R., 2011. The value of estuarine and coastal ecosystem services. Ecological Monographs, 81, 169-193.

Barr, J.G., Engel, V., Fuentes, J.D., Zieman, J.C., O'Halloran, T.L., Smith, T.J., Anderson, G.H., 2010. Controls on mangrove forest-atmosphere carbon dioxide exchanges in western Everglades National Park. J Geophys Res-Biogeo., 115.

Barr, J.G., Engel, V., Smith, T.J., Fuentes, J.D., 2012. Hurricane disturbance and recovery of energy balance, $\mathrm{CO} 2$ fluxes and canopy structure in a mangrove forest of the Florida Everglades. Agricultural and Forest Meteorology, 153, 54-66.

Barr, J.G., Fuentes, J.D., DeLonge, M.S., O'Halloran, T.L., Barr, D., Zieman, J.C., 2013. Summertime influences of tidal energy advection on the surface energy balance in a mangrove forest. Biogeosciences, 10, 501-511.

Blanco, R.I., Naja, G.M., Rivero, R.G., Price, R.M., 2013. Spatial and temporal changes in groundwater salinity in South Florida. Applied Geochemistry, 38, 48-58.

Bouillon, S., Borges, A.V., Castaneda-Moya, E., Diele, K., Dittmar, T., Duke, N.C., Kristensen, E., Lee, S.Y., Marchand, C., Middelburg, J.J., Rivera-Monroy, V.H., Smith, T.J., Twilley, R.R., 2008. Mangrove production and carbon sinks: A revision of global budget estimates. Global Biogeochemical Cycles 22.

Caldeira, K., 2012. Avoiding mangrove destruction by avoiding carbon dioxide emissions. Proceedings of the National Academy of Sciences of the United States of America, 109, $14287-14288$.

Campbell, A., Miles, L., Lysenko, I., Gibbs, H., Hughes, A., 2008. Carbon storage in protected areas. Technical report. UNEP World Conservation Monitoring Centre. 
Carter, N.T., 2002. South Florida ecosystem restoration and the Comprehensive Everglades Restoration Plan. CRS report for Congress. Order code RS20702. Congressional Research Service, The Library of Congress.

Castañeda-Moya, E., Twilley, R.R., Rivera-Monroy, V.H., Zhang, K., Davis, S., Ross, M., 2010. Sediment and nutrient deposition associated with hurricane Wilma in mangroves of the Florida Coastal Everglades. Estuaries and Coasts, 33, 45-58.

Castañeda-Moya, E., Twilley, R.R., Rivera-Monroy, V. H., Marx, B. D., Coronado-Molina, C., Ewe, S.M.L., 2011. Patterns of root dynamics in mangrove forests along environmental gradients in the Florida Coastal Everglades, USA. Ecosystems, 14, 1178-1195.

Castañeda-Moya, E., Twilley, R.R., Rivera-Monroy, V.H., 2013. Allocation of biomass and net primary productivity of mangrove forests along environmental gradients in the Florida Coastal Everglades, USA. Forest Ecology and Management, 307, 226-241.

Chapin, F.S., Woodwell, G.M., Randerson, J.T., Rastetter, E.B., Lovett, G.M., Baldocchi, D.D., Clark, D.A., Harmon, M.E., Schimel, D.S., Valentini, R., Wirth, C.,. Aber, J.D, Cole, J.J., Goulden, M.L., Harden, J.W., Heimann, M., Howarth, R.W., Matson P.A., McGuire, A.D., Melillo, J.M., Mooney, H.A., Neff, J.C., Houghton, R.A., Pace, M.L., Ryan, M.G., Running, S.W., Sala, O.E., Schlesinger, W.H., Schulze, E.D., 2006. Reconciling carboncycle concepts, terminology, and methods. Ecosystems, 9, 1041-1050.

Chave, J.,. Condit, R., Aguilar, S., Hernandez, A., Lao, S., Perez, R., 2004. Error propagation and scaling for tropical forest biomass estimates. Philosophical Transactions of the Royal Society of London Series B-Biological Sciences, 359, 409-420.

Chen, R., Twilley, R.R., 1999a. Patterns of mangrove forest structure and soil nutrient dynamics along the Shark River Estuary, Florida. Estuaries, 22, 955-70.

Chen, R., Twilley, R.R., 1999b. A simulation model of organic matter and nutrient accumulation in mangrove wetlands soils. Biogeochemistry, 44, 93-118.

Childers, D.L., 2006. A synthesis of long-term research by the Florida Coastal Everglades LTER Program. Hydrobiologia, 569, 531-544.

Clark, S., Bolt, K., Campbell, A., 2008. Protected areas: an effective tool to reduce emissions from deforestation and forest degradation in developing countries? Working Paper, UNEP World Conservation Monitoring Centre, Cambridge, U.K.

Collins, S.L., Carpenter, S.R., Swinton, S.M., Orenstein, D.E., Childers, D.L., Gragson, T.L., Grimm, N.B., Grove, M., Harlan, S.L., Kaye, J.P., Knapp, A.K., Kofinas, G.P., Magnuson, J.J.,. McDowell, W.H, Melack, J.M., Ogden, L.A., Robertson, G.P., Smith, M.D., Whitmer, A.C., 2011. An integrated conceptual framework for long-term social-ecological research. Frontiers in Ecology and the Environment, 9, 351-357. 
602

603

604

605

606

607

608

609

610

611

612

613

614

615

616

617

618

619

620

621

622

623

624

625

626

627

628

629

630

Coronado-Molina, C., Day, J.W., Reyes, E., Perez, B.C., 2004. Standing crop and aboveground biomass partitioning of a dwarf mangrove forest in Taylor River, Slough, Florida. Wetlands Ecology and Management, 12(3), 157-164.

Desmond, G., 2003. Measuring and mapping the topography of the Florida Everglades for ecosystem restoration, GEER Conference Greater Everglades Science Program : 2002 Biennial Report. U.S. Geological Survey.

Ding, H., Dias Nunes, P.A., Teelucksingh, S.S., 2010. European forests and carbon sequestration services: An economic assessment of climate change impacts. Working Paper no. 9. Ecosystem Services Economics, Nairobi, Kenya.

Donato, D.C., Kauffman, J.B., Murdiyarso, D., Kurnianto, S., Stidham, M., Kanninen, M., 2011. Mangroves among the most carbon-rich forests in the tropics. Nature Geoscience, 4, 293297.

Donato, D.C., Kauffman, J.B., Mackenzie, R.A., Ainsworth, A., Pfleeger, A.Z., 2012. Wholeisland carbon stocks in the tropical Pacific: Implications for mangrove conservation and upland restoration. Journal of Environmental Management, 97, 89-96.

Duque-Estrada, G.C., Soares, M.L.G., Fernandez, V., de Almeida, P.M.M., 2015. The economic valuation of carbon storage and sequestration as ecosystem services of mangroves: a case study from southeastern Brazil. International Journal of Biodiversity Science, Ecosystem Services \& Management. 11(1), 29-35. doi: 10.1080/21513732.2014.963676.

Ewe, S.M.L., Gaiser, E.E., Childers, D.L., Iwaniec, D., River-Monroy, V.H., Twilley, R.R., 2006. Spatial and temporal patterns of aboveground net primary productivity (ANPP) along two fresh-water estuarine transects in the Florida Coastal Everglades. Hydrobiologia, 569, 459-474.

Ewel, K.C., Twilley, R.R., Ong, J.E., 1998. Different kinds of mangrove forests provide different goods and services. Global Ecology and Biogeography, 7, 83-94.

Ezcurra, P., Ezcurra, E., Garcillán, P.P., Costa, M.T., Aburto-Oropeza, O., 2016. Coastal landforms and accumulation of mangrove peat increase carbon sequestration and storage. Proceedings of the National Academy of Sciences, 113 (16), 4404-4409.

Farfán, L.M., D’Sa, E., Liu, K., Rivera-Monroy, V.H., 2014. Tropical Cyclone Impacts on Coastal Regions: the Case of the Yucatán and the Baja California Peninsulas, Mexico. Estuaries and Coasts, 37: 1388. doi:10.1007/s12237-014-9797-2.

Forest Trends Ecosystem Marketplace, 2015. Ahead of the Curve: State of the Voluntary Carbon Markets, 2015. Forest Trends' Ecosystem Marketplace 1203 19th Street, NW 4th floor Washington, DC 20036, Available: http://foresttrends.org/releases/uploads/SOVCM2015_FullReport.pdf 
Friess, D., Phelps, J., Garmendia, E. and Gómez-Baggethun, E., 2015. "Payments for Ecosystem Services (PES) in the face of external biophysical stressors." Global Environment Change, 30, 31-42.

Fromard, F., Puig, H., Mougin, E., Marty, G., Betoulle, J., \& Cadamuro, L., 1998. Structure, above-ground biomass and dynamics of mangrove ecosystems: New data from French Guiana. Oecologia, 115, 39-53.

Fuentes, J.D., Barr, J.G., 2015. Mangrove forests and carbon and water cycling. Agricultural and Forest Meteorology 213, 263-265.

Giri, C., Ochieng, E., Tieszen, L.L., Zhu, Z., Singh, A., Loveland, T., Masek, J., Duke, N., 2011. Status and distribution of mangrove forests of the world using earth observation satellite data. Global Ecology and Biogeography, 20, 154-159.

Hamilton, S.E., Lovette, J., 2015. Ecuador's Mangrove Forest Carbon Stocks: A Spatiotemporal Analysis of Living Carbon Holdings and Their Depletion since the Advent of Commercial Aquaculture. Plos One 10. doi: 10.1371/journal.pone.0118880.

Harris, D., Horwath, W.R., van Kessel, C., 2001. Acid fumigation of soils to remove carbonates prior to total organic carbon or carbon-13 isotopic analysis. Soil Sci. Soc. Am. J., 65, 18531856.

Hessen, D.O., Agren, G.I., Anderson, T.R., Elser, J.J., De Ruiter, P.C., 2004. Carbon, sequestration in ecosystems: The role of stoichiometry. Ecology, 85, 1179-1192.

Ho, D.T., Ferron, S., Engel, V.C., Larsen, L.G., Barr, J.G., 2014. Air- water gas exchange and $\mathrm{CO}_{2}$ flux in a mangrove-dominated estuary. Geophysical Research Letters, 41, 108-113.

Hopkinson, C.S., Cai, W.J., Hu, X.P., 2012. Carbon sequestration in wetland dominated coastal systems - a global sink of rapidly diminishing magnitude. Current Opinion in Environmental Sustainability, 4, 186-194.

Interagency Working Group on Social Cost of Carbon, United States Government, 2013. Technical update of the social cost of carbon for regulatory impact analysis under Executive Order 12866. May 2013. United States Government.

IPCC, 2007. Climate change 2007 - The physical science basis: Working Group 1 contribution to the Fourth Assessment Report of the IPCC. Cambridge University Press, Cambridge.

Kauffman, J.B., Heider, C., Cole, T.G., Dwire, K.A., Donato, D.C., 2011. Ecosystem carbon stocks of Micronesian mangrove forests. Wetlands, 31, 343-352.

Kauffman, J.B., Heider, C., Norfolk,J., Payton, F., 2014. Carbon stocks of intact mangroves and carbon emissions arising from their conversion in the Dominican Republic Carbon stocks of mangroves and carbon emissions. Ecological Applications, 24(3), 518-527. 
Maher, D.T., Santos, I.R., Golsby-Smith, L., Gleeson, J., Eyre, B.D., 2013. Groundwater-derived dissolved inorganic and organic carbon exports from a mangrove tidal creek: The missing mangrove carbon sink? Limnology and Oceanography, 58, 475-488.

McCormick, B., Clement, R., Fischer, D., Lindsay, M., Watson, R., 2010. Measuring the economic benefits of America's Everglades' restoration. Mather Economics, Palmetto Bay, Florida: Everglades Foundation.

McGranahan, G., Balk, D., Anderson, B., 2007. The rising tide: assessing the risks of climate change and human settlements in low elevation coastal zones. Environment and Urbanization 19, 17-37.

Meriwether, J.R., Sheu, W.J., Hardaway, C., Beck, J.N., 1996. Coring sampler for chemical analysis of soft sediments. Microchemical Journal, 53, 201-206.

Murdiyarso, D., Purbopuspito, J., Kauffman, J.B., Warren, M.W., Sasmito, S.D., Donato, D.C., Manuri, S., Krisnawati, H., Taberima, S., Kurnianto, S., 2015. The potential of Indonesian mangrove forests for global climate change mitigation. Nature Climate Change, 5, 10891092.

Nagelkerken, I., Blaber, S.J.M., Bouillon, S., Green, P., Haywood, M., Kirton, L.G., Meynecke, J.O., Pawlik, J., Penrose, H.M., Sasekumar, A., Somerfield, P.J., 2008. The habitat function of mangroves for terrestrial and marine fauna: A review. Aquatic Botany, 89, 155-185.

Noe, G., Childers, D.L., Jones, R.D., 2001. Phosphorus biogeochemistry and the impacts of phosphorus enrichment: Why are the Everglades so unique? Ecosystems, 4, 603-624.

Pan, Y., Birdsey, R.A., Fang, J., Houghton, R., Kauppi, P.E., Kurz, W.A., Phillips, O.L., Shvidenko, A., Lewis, S.L., Canadell, J.G., Ciais, P., Jackson, R.B., Pacala, S.W., McGuire A.D., Piao, S., Rautiainen, A., Sitch, S., Hayes, D., 2011. A large and persistent carbon sink in the world's forests. Science, 333, 988-993.

Potomac Enterprises (2015). Annual resort on the market for RGGI $\mathrm{CO}_{2}$ allowances: 2014. Retrieved from http://rggi.org/docs/Market/MM_2014_Annual_Report.pdf. Pp. 6-7.

Price, R., Thornton, S., Nelson, S., 2007. The social cost of carbon and the shadow price of carbon: What they are, and how to use them in economic appraisal in the UK. London, U.K.: Economics Group, Department for Environment, Food and Rural Affairs.

Ramirez, O.A., Carpio, C.E., Ortiz, R., Finnegan, B., 2002. Economic value of carbon sink services of tropical secondary forests and its management implications. Environmental and Resource Economics, 21, 23-46.

Rivera-Monroy, V.H., Twilley, R.R., Bone, D., Childers, D.L., Coronado-Molina, C., Feller, I.C., Herrera-Silvereira, J., Jaffe, R., Mancera, E., Rejmankova, E., Salisbury, J.E., Weil, E., 
2004. A conceptual framework to develop long-term ecological research and management objectives in the wider Caribbean region. Bioscience, 54, 843-856.

Rivera-Monroy, V.H., Twilley. R.R., Davis, S.E., Childers, D.L., Simard, M., Chambers, R.M., Jaffe, R., Boyer, J.N., Rudnick, D.T., Zhang, K., Castaneda-Moya, E., Ewe, S.M.L., Price, R.M., Coronado-Molina, C., Ross, M.S., Smith, T.J., Michot, B., Meselhe, E., Nuttle, W.K., Troxler, T., Noe, G.B., 2011a. The role of the Everglades Mangrove Ecotone Region (EMER) in regulating nutrient cycling and wetland productivity in South Florida. Critical Reviews in Environmental Science and Technology, 41, 633-669.

Rivera-Monroy, V. H., Delaune, R.D., Owens, A.B., Visser, J., White, J.R., Twilley, R.R., Hernandez-Trejo, H., Benitez, J.A., 2011b. Removal of physical materials from systems: Loss of space, area, and habitats. In Wolanski, E., McLusky, D.S. (Eds.), Treatise on Estuarine and Coastal Science. Waltham: Academic Press, pp. 185-215.

Rivera-Monroy, V.H., Castañeda-Moya, E., Barr, J.G., Engel, V., Fuentes, J.D., Troxler, T.G., Twilley, R.R., Bouillon, S., Smith, T.J., O’Halloran, T.L., 2013. Current methods to evaluate net primary production and carbon budgets in mangrove forests, In: DeLaune, R.D., Reddy, K.R., Megonigal, P., Richardson, C. (Eds.), Methods in Biogeochemistry of Wetlands. Soil Science Society of America Book Series, pp. 243-288.

Ross, M.S., Meeder, J.F., Sah, J.P., Ruiz, L.P., Telesnicki, G.J., 2000. The Southeast saline Everglades revisited: 50 years of coastal vegetation change. Journal of Vegetation Science $11,101-112$.

Ross, M.S., O'Brien, J.J., Ford, R.G., Zhang, K.Q., Morkill, A., 2009. Disturbance and the rising tide: the challenge of biodiversity management on low-island ecosystems. Frontiers in Ecology and the Environment, 7, 471-478.

Rovai, A.S., Riul, P., Twilley, R.R., Castaneda-Moya, E., Rivera-Monroy, V.H., Williams, A.A., Simard, M., Cifuentes-Jara, M., Lewis, R.R., Crooks, S., Horta, P.A., Schaeffer-Novelli, Y., Cintron, G., Pozo-Cajas, M., Pagliosa, P.R., 2016. Scaling mangrove aboveground biomass from site-level to continental-scale. Global Ecology and Biogeography, 25, 286298.

Saha, A.K., Moses, C.S., Price, R.M., Engel, V., Smith, T.J., Anderson, G., 2012. A hydrological budget (2002-2008) for a large subtropical wetland ecosystem indicates marine groundwater discharge accompanies diminished freshwater flow. Estuaries and Coasts, 35, 459-474.

Siikamäki, J., Sanchirico, J.N., Jardine, S.L., 2012. Global economic potential for reducing carbon dioxide emissions from mangrove loss. PNAS. doi: 10.1073/pnas.1200519109.

Simard, M., Zhang, K., Rivera-Monroy, V., Ross, M.S., Ruiz, P.L., Castañeda-Moya, E., Twilley, R.R., Rodriguez, E., 2006. Mapping height and biomass of mangrove forests in the Everglades National Park with SRTM elevation data. Photogrammetric Engineering and Remote Sensing, 72, 299-312. 
Simard, M., Rivera-Monroy, V.H., Mancera-Pineda, J.E., Castañeda-Moya, E., Twilley, R.R., 2008. A systematic method for 3D mapping of mangrove forests based on Shuttle Radar Topography Mission elevation data, ICEsat/GLAS waveforms and field data: Application to Ciénaga de Santa Marta, Colombia. Remote Sensing of Environment, 112, 2131-2144.

Sklar, F. H., Fitz, H.C., Wu, Y., Van Zee, R., Mcvoy, C., 2001. The design of ecological landscape models for Everglades restoration. Ecological Economics, 37, 379-401.

Sklar, F.H., Chimney, M.J., Newman, S., McCormick, P., Gawlik, D., Miao, S.L., McVoy, C., Said, W., Newman, J., Coronado, C., Crozier, G., Korvela, M., Rutchey, K., 2005. The ecological-societal underpinnings of Everglades restoration. Frontiers in Ecology and the Environment, 3, 161-169.

Smith T.J. III, Harold Hudson, J., Robblee, M.B., Powell, G.V.N., Isdale, P.J., 1989. Freshwater flow from the Everglades to Florida Bay: a historical reconstruction based on fluorescent banding on the coral Solenastrea Bournoni. Bulletin of Marine Science, 44, 274-282.

Smith, T.J. III, Whelan, K.R.T., 2006. Development of allometric relations for three mangrove species in South Florida for use in the Greater Everglades Ecosystem restoration. Wetlands Ecology and Management, 14, 409-419.

Smith, T.J. III, Anderson, G.H., Balentine, K., Tiling, G., Ward, G.A., Whelan, K.R.T., 2009. Cumulative impacts of hurricanes on Florida mangrove ecosystems: Sediment deposition, storm surges, and vegetation. Wetlands, 29, 24-34.

Stockmann, U., Adams, M.A., Crawford, J.W., Field, D.J., Henakaarchchi N., Jenkins, M., Minasny, B., McBratney, A.B., de Courcelles, V.D., Singh, K., Wheeler, I., Abbott, L., Angers, D.A., Baldock, J., Bird, M., Brookes, P.C., Chenu, C., Jastrowh, J.D., Lal, R., Lehmann, J., O'Donnell, A.G., Parton, W.J., Whitehead, D., Zimmermann, M., 2013. The knowns, known unknowns and unknowns of sequestration of soil organic carbon. Agriculture Ecosystems \& Environment, 164, 80-99.

Suarez-Abelenda, M., Ferreira, T.O., Camps-Arbestain, M.,Rivera-Monroy, V.H., Macias, F., Nuto Nóbrega, G., Otero, X.L., 2014. The effect of nutrient-rich effluents from shrimp farming on mangrove soil carbon storage and geochemistry under semi-arid climate conditions in northern Brazil. Geoderma, 213, 551-559.

Taylor, J.R., 1997. An Introduction to Error Analysis: The Study of Uncertainties in Physical Measurements, second. Sausalito, California: University Science Books.

Troxler, T.G., Gaiser, E., Barr, J., Fuentes, J.D., Jaffé, R., Childers, D.L., Collado-Vides, L., Rivera-Monroy, V.H., Castañeda-Moya, E., Anderson, W., Chambers, R., Chen, M., Coronado-Molina, C., Davis, S.E., Engel, V., Fitz, C., Fourqurean, J., Frankovich, T., Kominoski, J., Madden, C., Malone, S.L., Oberbauer, S.F., Olivas, P., Richards, J., Saunders, C., Schedlbauer, J., Scinto, L.J., Sklar, F., Smith, T., Smoak, J.M., Starr, G., Twilley, R.R., Whelan, K.R.T., 2013. Integrated carbon budget models for the Everglades 
782

terrestrial-coastal-oceanic gradient: Current status and needs for inter-site comparisons. Oceanography, 26, 98-107.

Troxler, T.G., Barr, J.G., Fuentes, J.D., Engel, V., Anderson, G., Sanchez, C., Lagomasino, D., Price, R., Davis, S.E., 2015. Component-specific dynamics of riverine mangrove $\mathrm{CO}_{2}$ efflux in the Florida coastal Everglades. Agricultural and Forest Meteorology, 213, 273-282.

Twilley, R.R., Rivera-Monroy, V.H., 2009. Ecogeomorphic models of nutrient biogeochemistry for mangrove wetlands, in: Perillo, G.M.E., Wolanski, E., Cahoon, D.R., Brinson, M.M. (Eds.), Coastal Wetlands: An Integrated Ecosystem Approach. Elsevier, New York, NY, pp. 641-675.

Valiela, I., Bowen, J.L., York, J.K., 2001. Mangrove forests: One of the world's threatened major tropical environments. BioScience, 51, 807-815.

Yao, Q., Liu, K.-b., Platt, W.J., Rivera-Monroy, V.H., 2015. Palynological reconstruction of environmental changes in coastal wetlands of the Florida Everglades since the midHolocene. Quaternary Research, 83, 449-458.

Zarate-Barerra. T.G., Maldonado, J.H., 2015. Valuing blue carbon: Carbon sequestration benefits provided by the marine protected areas in Colombia. PLoS ONE 10(5):e0126627.

Zhang, K.Q., Liu, H., Li, Y. Xu, H. Shen, J. Rhome, J., 2012. The role of mangroves in attenuating storm surges. Estuarine Coastal and Shelf Science, 102, 11-23. 


\section{Tables}

Table 1. Mean ( $\pm 1 \mathrm{SE})$ above- $\left(\mathrm{C}_{\mathrm{AG}}\right)$ and below-ground carbon $\left(\mathrm{C}_{\mathrm{BGR}}\right)$ and soil carbon $\left(\mathrm{C}_{\mathrm{BGS}}\right)$ storages in mangrove sites throughout the Everglades Mangrove Ecotone Region (EMER). Soil stocks are estimated to a depth of $0.9 \mathrm{~m}$ except where noted (i.e., Taylor River sites).

\begin{tabular}{|c|c|c|c|c|c|}
\hline \multirow{4}{*}{$\begin{array}{l}\text { FCE-LTER } \\
\text { Study Site }\end{array}$} & \multirow{4}{*}{$\begin{array}{l}\text { Dominant } \\
\text { Species }\end{array}$} & \multirow{2}{*}{$\begin{array}{l}\text { Aboveground } \\
\text { Carbon }^{a} \\
\text { (MgC/ha) }\end{array}$} & \multirow{4}{*}{$\begin{array}{c}\text { Belowground Root } \\
\text { Carbon }^{c} \\
(\mathrm{MgC} / \mathrm{ha}) \\
(0.9 \mathrm{~m}) \\
\left(\mathrm{C}_{\mathrm{BGR}}\right) \\
\end{array}$} & \multirow{4}{*}{$\begin{array}{l}\text { Soil Organic Carbon } \\
\qquad \begin{array}{c}(\mathrm{MgC} / \mathrm{ha})^{d} \\
(0.9 \mathrm{~m}) \\
\left(\mathrm{C}_{\mathrm{BGS}}\right)\end{array}\end{array}$} & \multirow{4}{*}{$\begin{array}{c}\text { Total Organic } \\
\text { Carbon } \\
(\mathrm{MgC} / \mathrm{ha})\end{array}$} \\
\hline & & & & & \\
\hline & & & & & \\
\hline & & $\left(\mathrm{C}_{\mathrm{AG}}\right)$ & & & \\
\hline SRS-4 & $\begin{array}{l}\text { Rhizophora } \\
\text { mangle }\end{array}$ & $47.5 \pm 1.5^{*}$ & $14.1 \pm 1.8(n=5)$ & $373.8 \pm 23.8(\mathrm{n}=4)$ & $435.4^{*}$ \\
\hline SRS-5 & $\begin{array}{l}\text { Rhizophora } \\
\text { mangle }\end{array}$ & $42.0 \pm 0.3 *$ & $19.3 \pm 1.4(n=5)$ & $475.7 \pm 14.2(n=4)$ & $537^{*}$ \\
\hline SRS-6 & $\begin{array}{l}\text { Laguncularia } \\
\text { racemosa }\end{array}$ & $71.4 \pm 0.9 *$ & $11.1 \pm 1.9(n=5)$ & $365.6 \pm 7.7(n=4)$ & $448.1^{*}$ \\
\hline TS/Ph-6 & $\begin{array}{l}\text { Rhizophora } \\
\text { mangle }\end{array}$ & $5.5^{b}$ & $10.6 \pm 1.5(n=10)$ & $53.5 \pm 6.2(\mathrm{n}=4)$ & 69.6 \\
\hline TS/Ph-7 & $\begin{array}{l}\text { Rhizophora } \\
\text { mangle }\end{array}$ & $5.5^{b}$ & $20.6 \pm 3.3(n=7)$ & $224.8 \pm 13.9(n=4)$ & 250.9 \\
\hline TS/Ph-8 & $\begin{array}{l}\text { Rhizophora } \\
\text { mangle }\end{array}$ & $1.97 \pm 0.2$ & $19.2 \pm 3.2(\mathrm{n}=5)$ & $163.5 \pm 5.1(n=3)$ & 184.7 \\
\hline Median & & 23.8 & 16.7 & 295.2 & $335.6 \pm 88.1$ \\
\hline Mean $\pm S E$ & & $29.8 \pm 11.8(n=6)$ & $15.8 \pm 1.8(n=6)$ & $276.1 \pm 63.8(n=6)$ & $321 \pm 73.6$ \\
\hline
\end{tabular}

${ }^{\mathrm{a} C}$ Castañeda-Moya et al. (2013);

${ }^{\mathrm{b}}$ Coronado-Molina et al. 2004, values for TS/Ph-6 and TS/Ph-7 do not have standard error in original source;

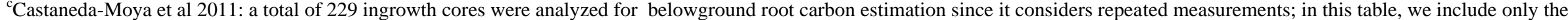
total $\mathrm{N}$ value representing the number of sampling points at two depths $(0-0.45 \mathrm{~m}$ and $0.45-0.90 \mathrm{~m})$;

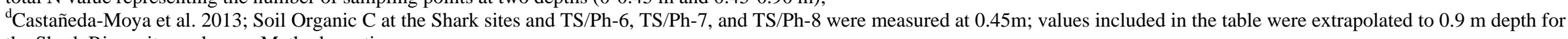
the Shark River sites only- see Methods section;

*ANOVA significant differences between Shark River and Taylor: 
Aboveground Carbon: Shark River $=53.5 \pm 9.0(\mathrm{SE})$, Taylor River $=4.3 \pm 1.2(\mathrm{SE})$. Total Organic Carbon $(\mathrm{MS}=3647.1, \mathrm{~F}$ ratio $=29.3, \mathrm{P}>\mathrm{F}, 0.005)$

Total Organic Carbon: Shark River $=473.5 \pm 31.9$ (SE), Taylor River $=168.4 \pm 52.9$ (SE). Total Organic Carbon $(\mathrm{MS}=139629, \mathrm{~F}$ ratio $=24.3, \mathrm{P}>\mathrm{F}, 0.007)$ 
Table 2. Economic Valuation of C Storage in the Mangrove Forest of the Everglades National Park, Florida (in 2015 US\$)

\begin{tabular}{|c|c|c|c|c|}
\hline & $\begin{array}{l}\text { Total Organic Carbon } \\
\text { in ENP Mangroves } \\
(\mathrm{MgC} / \mathrm{ha})\end{array}$ & $\begin{array}{l}\text { Average } \\
\text { Abatement Cost } \\
\text { for ENP } \\
\text { mangroves } \\
\left(\$ / \mathrm{tC}^{\mathrm{a}}\right)\end{array}$ & $\begin{array}{l}\text { Economic Valuation of } \\
\text { C stored in } \\
\text { ENP mangroves per ha } \\
(\$ / \text { ha })\end{array}$ & $\begin{array}{l}\text { Economic Valuation } \\
\text { of total C storage in } \\
\text { ENP mangrove } \\
\text { forests } b \\
\text { (\$) }\end{array}$ \\
\hline Median - SE Value & 247.5 & \multirow{3}{*}{56} & 13,860 & $2,002,035,420$ \\
\hline Median Value & 335.6 & & 18,794 & $2,714,679,139$ \\
\hline Median + SE Value & 423.7 & & 23,727 & $3,427,322,858$ \\
\hline \multicolumn{5}{|c|}{$\begin{array}{l}\text { Notes: } \\
{ }^{\mathrm{a}} 1 \mathrm{tC}=1 \text { metric ton Carbon }=1 \mathrm{MgC} ; \\
{ }^{\mathrm{b} E N P} \text { mangrove forest area: } 144,447 \mathrm{ha} . \\
\text { Total Organic Carbon (median value) in ENP mangroves: } 335.6 \mathrm{MgC} / \mathrm{ha} * 144,447 \mathrm{ha}=48,476,413 \mathrm{MgC} \text {. } \\
\text { The median economic value for ENP mangroves based on: } \\
\text { SCC }(\$ 167 / \mathrm{tC})=\$ 56,045 / \mathrm{ha} \text {. } \\
\text { RGGI market price }(\$ 18 / \mathrm{tC})=\$ 6,041 / \mathrm{ha} . \\
\text { International voluntary market price }(\$ 14.36 / \mathrm{tC})=\$ 4,819 / \mathrm{ha} .\end{array}$} \\
\hline
\end{tabular}




\section{Figure}

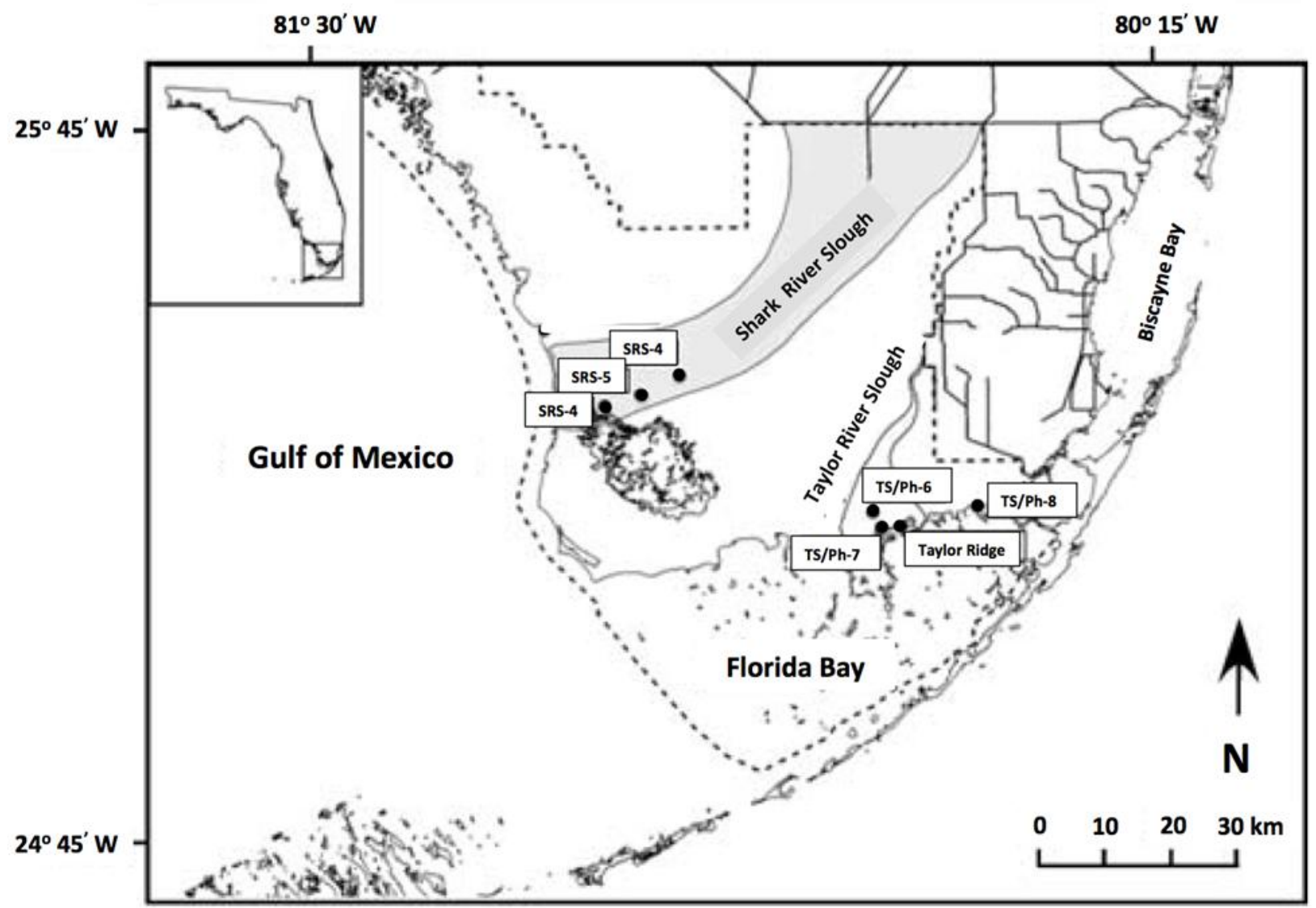

Figure 1: Map of South Florida showing spatial distribution and location of the Taylor and Shark River sloughs in the Everglades National Park, Florida (Source: FCE LTER, http://fcelter.fiu.edu/) 